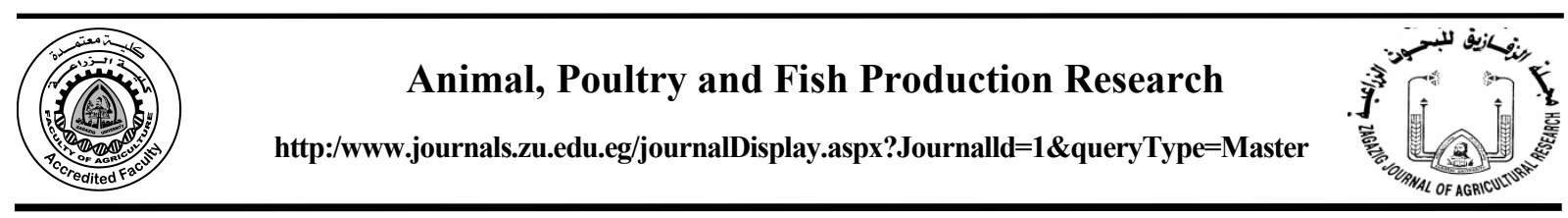

\title{
BIOLOGY AND POPULATION DYNAMIC OF BLUE SWIMMING CRAB Portunus pelagicus IN BARDAWILL LAGOON, NORTH SINAI, EGYPT
}

\author{
Mohamed S. Ahmed* \\ Fac. Aquac. and Marine Fisheries, Arish Univ., Egypt \\ Received: 02/04/2019 ; Accepted: 12/05/2019
}

\begin{abstract}
Crabs are considered non-native crustacean species in Bardawill lagoon which require more studies. Length frequency analysis were used to estimate size distribution, growth, maturity, mortality and yield per recruit of Blue swimming crab, Portunus pelagicus in Bardawill lagoon during the fishing season 2016. Samples were obtained from trammel fishing vessels. Carapace width of 1068 samples ranged from 4.7 to $13.4 \mathrm{~cm}$ and total weight from 10.4 to $198.3 \mathrm{~g}$. Size distribution showed the major portion of the catch ranged of 8 to $10.9 \mathrm{~cm}$ carapace width. FiSAT II computer program was used to estimate the growth parameters as $\mathrm{L} \infty=14.3 \mathrm{~cm}$ and $\mathrm{K}=1.1 \mathrm{yr}^{-1}$. The growth performance index ( $\left.\varnothing^{\prime}\right)$ equal 2.358. Recruitment was extent from June to October. Sex ratio between male and female were 1.09: 1 . The size at first maturity $\left(\mathrm{CWm}_{50}\right)$ was estimated at $9.1 \mathrm{~cm}$. Total, natural and fishing mortality rates were $4.25 \mathrm{yr}^{-1}, 1.6 \mathrm{yr}^{-1}$ and $2.65 \mathrm{yr}^{-1}$, respectively. Size at first capture $\left(\mathrm{CWc}_{50}\right)$ was $8.6 \mathrm{~cm}$. So, stock of Blue crab in Bardawill lagoon should be controlled by increased the fishing effort and adding unconventional fishing methods such as traps with traditional fishing such as trammel, trawlers and gillnetters, as this species may be become dangerous on native species in region.
\end{abstract}

Key words: Portunus pelagicus, bardawill lagoon, growth parameters and population biology.

\section{INTRODUCTION}

Bardawill lagoon is not native region for crabs. Blue swimming crab Portunus pelagicus occurred in the Eastern Mediterranean Sea as a Lessepsian migrant (Smith, 1982; Foka et al., 2004). Bardawill lagoon is characterized by its catches of economic fishes as Bream, Bass and Sole fish. Oftentimes, crabs are seen as an annoying species in fishers' gears. In past few years, crabs have increased dramatically in catches, which have almost dominated in productivity. Crabs was accounting for $41.9 \%$ of the total landing in the fishing season, 2015 (GAFRD, 2017). Despite the socio-economic importance of crab fishery in lagoon, many aspects have not been comprehensively studied. Some studies have been conducted of this species in the lagoon such as population biology (Abdel-Razek et al., 2006); Ecological and population dynamics (Emam, 2010) and age determination (Kilada and Ibrahim, 2016). Abdel-Razek et al. (2016) recorded two species in lagoon; P. pelagicus, $85 \%$ and Callinectas sapidus $15 \%$ only of total crab landings.

The relationship between invasive species and decline of native species is widely accepted by scientists. Crabs have not yet been determined are they wanted or unwanted species in Bardawill lagoon as invasive species may be having negative effects on fisheries as recorded by Walton et al. (2002) and Gurevitch and Padilla (2004). Growth, distribution, recruitment and reproductive strategy of this species may be makes a threat to lagoon in future. Biology and fishery of crab need of much an evaluation in relation to fishers' interests compared to native species and will be necessary to provide some information in an attempt to develop or control it in the future if it has any negative impact on the main catch in the lagoon. Therefore, this research was done of crab fishery.

\footnotetext{
* Corresponding author: Tel. : +20160016096

E-mail address: moha_sale@hotmail.com
} 


\section{MATERIALS AND METHODS}

This research was done in Bardawill lagoon (Fig. 1), eastern Mediterranean Sea.

Sampling was collected bimonthly (twice a month) for one fishing season from May to December, 2016. The research was cover three landing sites; west, central and east lagoon. Samples were collected from trammel fishing vessels with mesh sizes of 5.5 (square mesh $\approx 27$ $\mathrm{mm}$; the distance between two sequential knots) and $6.5 \mathrm{~cm}$ (square mesh $\approx 33 \mathrm{~mm}$ ). Samples were iced and taken to the laboratory for analysis. By U-shaped or V-shaped abdomen was determined the male and female individuals. Length frequency analyses of 1068 individuals (557 males and 511 females) were used to assess of blue swimming crab $P$. pelagicus stock. Carapace width (CW) base of the largest lateral carapace spines were measured to nearest 0.1 $\mathrm{cm}$. weight was recorded to the nearest 1 gram using a digital balance (one gram). Samples classified into one $\mathrm{cm}$ class intervals based on their carapace width $(\mathrm{CW})$.

ELEFAN-routine in FiSAT II computer program was run to estimate the growth parameters (L $\infty$ and $\mathrm{K})$ for fish stock assessment (Gayanilo et al., 2003).

Pauly's equation (Pauly, 1984) was used to calculate the theoretical 0 -age $\left(\mathrm{t}_{0}\right): \log _{10}-\mathrm{t}_{0}$ $=-0.3922-0.2752 \times \log (\mathrm{L} \infty)-1.038 \times \log (\mathrm{K})$.

von Bertalanffy growth equation was used to describe the growth as:

$$
\mathrm{CW}_{\mathrm{t}}=\mathrm{CW}_{\infty} \times\left(1-\mathrm{e}^{-\mathrm{k}}\left(\mathrm{t}-\mathrm{t}^{0)}\right)\right.
$$

Where:

$\mathrm{CW}_{\mathrm{t}}$ is the carapace width at time $\mathrm{t}$;

$\mathrm{CW}_{\infty}$ is the mean carapace width of very old crabs;

$\mathrm{K}$ is the von Bertalanffy growth coefficient;

$\mathrm{t}_{0}$ is the time at which carapace width is theoretically zero.

Growth performance index was given by Pauly and Munro (1984) equation:

$$
\varnothing=\log _{10} \mathrm{~K}+2 \log _{10} \mathrm{CW}_{\infty} .
$$

FiSAT II was used to obtain the monthly proportion of crab recruitment.
Sex ratio was differentiated by the abdominal shape. Length at first maturity was obtained by equation of Froese and Binohlan, (2000) as :

$$
\log \mathrm{L}_{\mathrm{m}}=0.8979 \times \log \left(\mathrm{L}_{\infty}\right)-0.0782 .
$$

The length-converted catch curve method (Pauly, 1983) was used to estimate the instantaneous rate of total mortality $(\mathrm{Z})$ by using the FiSAT program. Two methods were used to calculate the natural mortality $(\mathrm{M})$; Jensen (1996) by $\mathrm{M}=1.5 \times \mathrm{K}$ and Hewitt and Hoenig (2005) as $\mathrm{M}=4.22 / \mathrm{t}_{\max }$ ( $\mathrm{K}$ the body growth coefficient and $t_{\max }$ is the oldest fish). The fishing mortality $(\mathrm{F})$ calculated as $\mathrm{F}=\mathrm{Z}-\mathrm{M}$ and the exploitation rate $(E=F / Z)$. The probability of capture was estimated from length-converted catch curve, using the running average technique to determine $\mathrm{L}_{50}$.

\section{RESULTS AND DISCUSSION}

Carapace width of 1068 individuals of Blue swimming crab, Portunus pelagicus ranged from 4.7 to $13.4 \mathrm{~cm}$ (Fig. 2) and total weight ranged from 10.4 to $198.3 \mathrm{~g}$. Size distribution showed that the major portion of catch ranged between 8 to $10.9 \mathrm{~cm}(\mathrm{CW})$ of both sexes with disappeared of large sizes. This result was confirmed by Abdel-Razek et al. (2016), where they found the sizes of $85 \mathrm{~mm}$ to $115 \mathrm{~mm}(\mathrm{CW})$ were dominated in the same lagoon. Hosseini et al. (2012) found the size classes 110 to $130 \mathrm{~mm}$ were the highest frequency in Persian Gulf Coasts, Iran. These results indicated that small individuals are dominant in catches, which may be associated with poor growth due to unsuitable environmental conditions as a higher salinity. Studies indicate that salinity is effect on the growth of Portunidae crab (Baylon and Suzuki, 2007; Ikhwanuddin et al., 2012).

Monthly distribution of average sizes are presented in Fig. 3. The smallest size $(4.2 \mathrm{~cm})$ was recorded in May and the largest size (13.5 $\mathrm{cm})$ was reported in November.

Bertalanffy growth equation has the form of $\mathrm{CW}_{\mathrm{t}}=14.3 \times\left(1-\mathrm{e}^{-1.1(\mathrm{t}-(-0.177))}\right)$ in this study according to Rugolo et al. (1997) as resulted that, the Bertalanffy model adequately described blue crab widths at ages. The mean length distribution using a modal progression analysis was given cohort through its monthly growth progression (Fig. 4). 


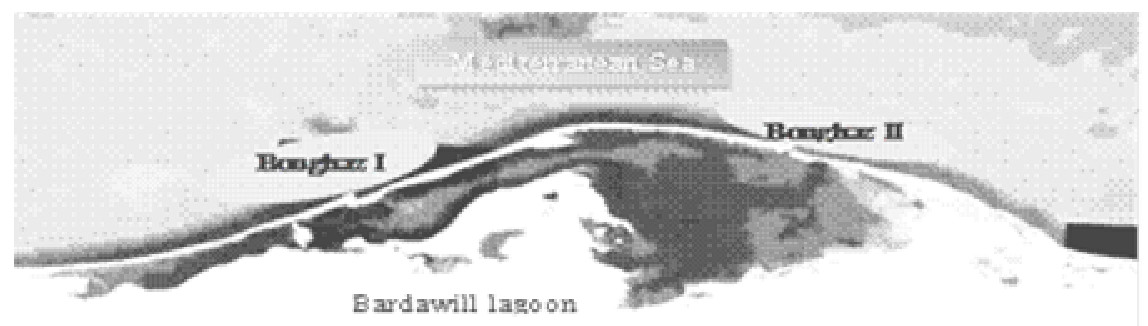

Wurth Sinel

Fig. 1. Bardawill lagoon

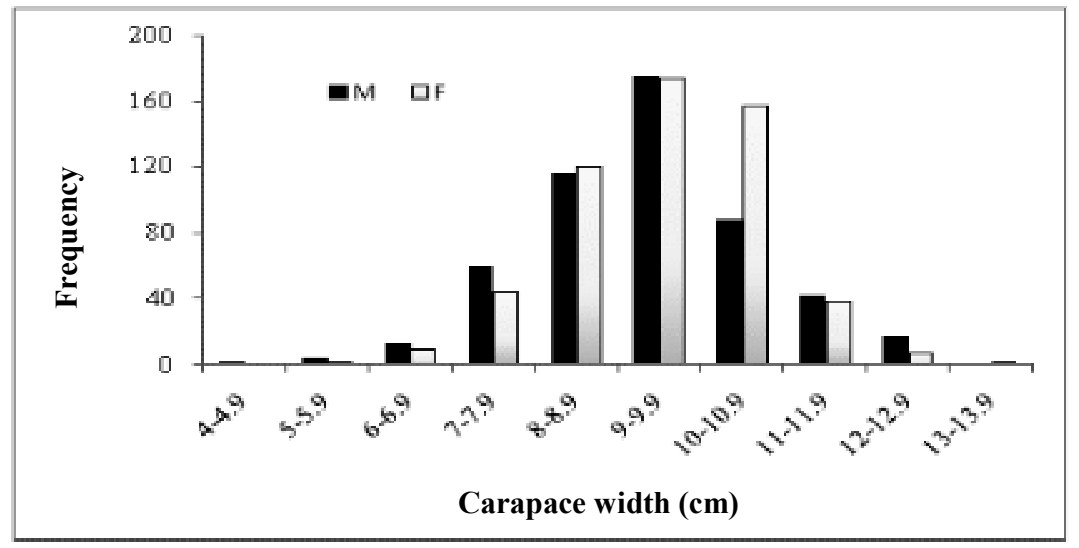

Fig. 2. Size distribution of Blue crab

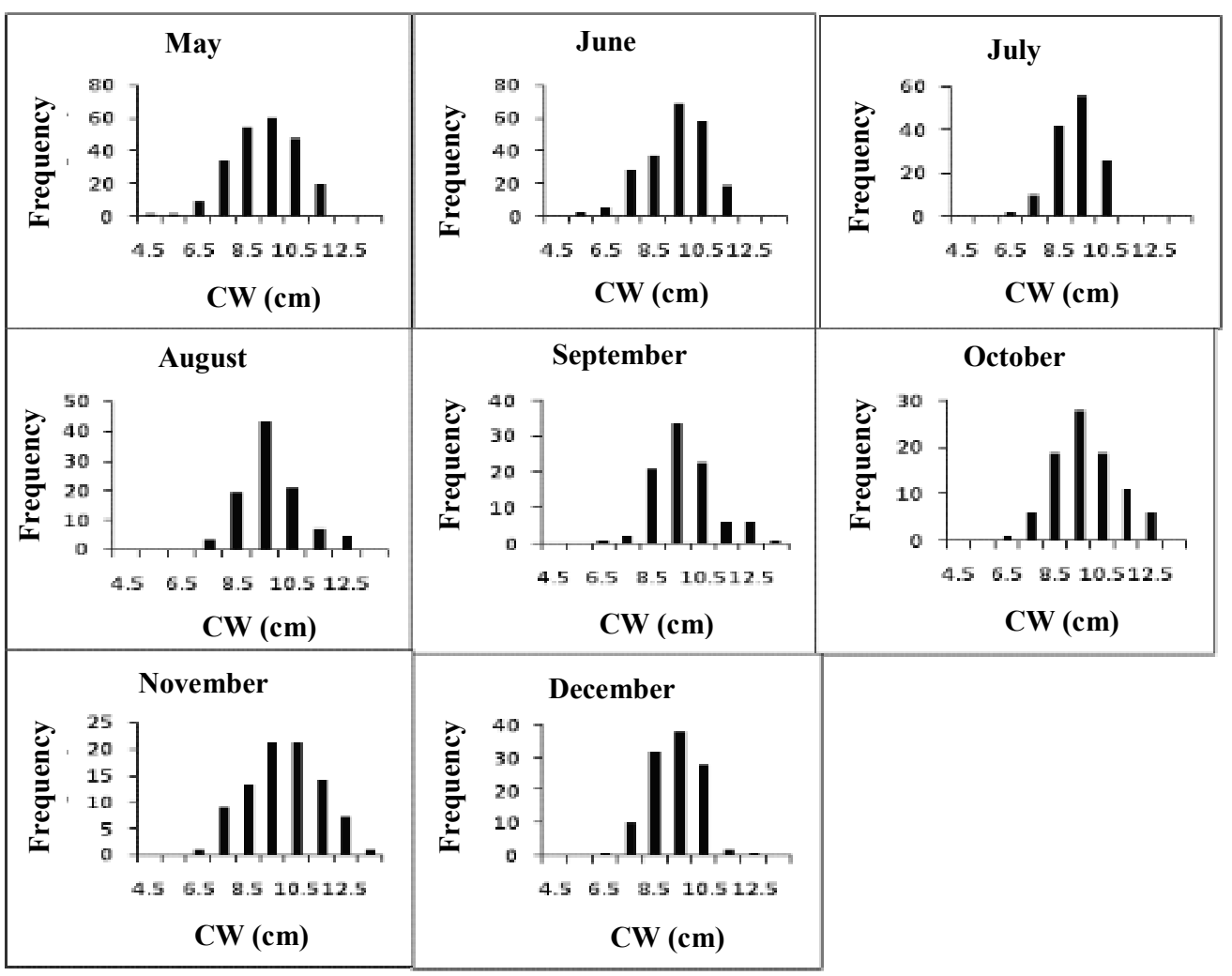

Fig.3. Monthly size (CW) distribution of Blue crab from Bardawill lagoon 


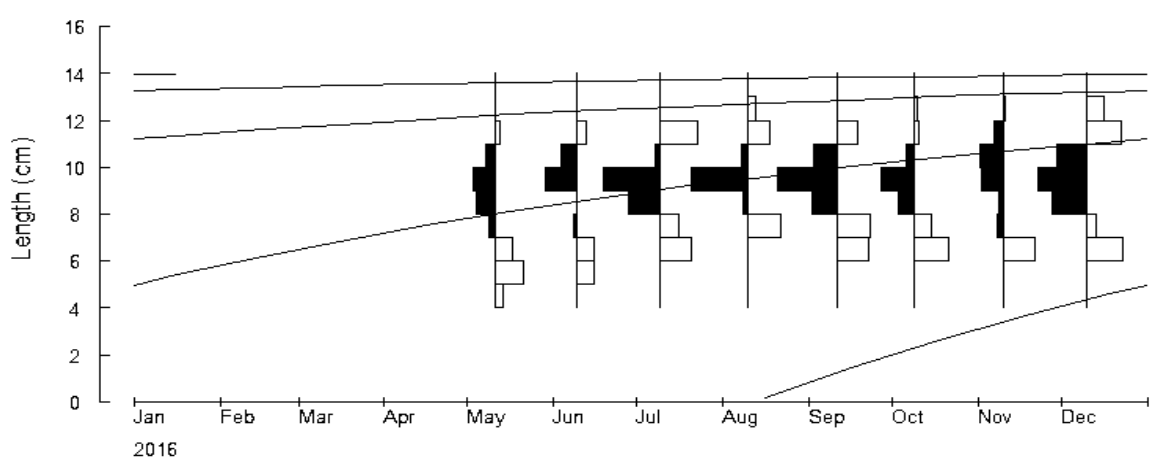

Fig. 4. Size-frequency distribution (CW) of Blue crab from Bardawill lagoon

Growth rate $(\mathrm{K}=1.1)$ has indicated a lower growth value comparing with another studies as: Josileen and Menon (2004) $(\mathrm{K}=1.7)$ in India; Mehanna and Haggag (2007) $(\mathrm{K}=1.4)$ in Mediterranean. These results are similar to the findings of Ehsan et al. (2010) in Northern Persian Gulf who found that $P$. pelagicus has $\mathrm{K}=1.2$ and 1.1 for male and female.

The growth performance index ( $\left.\varnothing^{\prime}\right)$ equal 2.358. Phi index is a lower that may be referring to unsuitable of hyper salinity in Bardawill lagoon for the growth of blue swimming crab. This result confirmed by Romano and Zeng (2006), Kunsook et al. (2014) and Green et al. (2014), they mentioned that temperature, salinity and availability of food effects on survival and growth of $P$. pelagicus. Afzaal et al. (2016) mentioned that the environmental conditions were favorable for the growth of blue swimming crab at $\varnothing^{\prime}=2.734$.

Recruitment of crabs in Bardawill lagoon takes throughout the fishing season with one peak which was extent from June to October (Fig. 5). Crab recruitment is influenced by many factors as water characteristics, fishing, sex ratio, predators, and disease (Sugilar et al., 2012; Green et al., 2014).

Sex ratio between male and female were 1.09: 1 . This ratio may be related to the age and population dynamics. A similar result was obtained by Kunsook et al. (2014) as males to females were 1:0.92 in Gulf of Thailand. The tendency of males to be more abundant than females is consistent with the observations of Abdul-Razek et al. (2016) and Jayawiguna et al. (2017).
The size at first maturity $\left(\mathrm{CWm}_{50}\right)$ was estimated at $9.1 \mathrm{~cm}$. It was observed that sexual maturity in blue crabs was early in the study area with the findings of Potter et al. (1998) in the Peel-Harvey Estuary, Western Australia, as noted that $50 \%$ of the crabs become mature at 98 $\mathrm{mm}$. Fisher (1999) evinced that the size at maturity in blue crabs decreases with increases in salinity and temperature. Dineshbabu et al. (2008) stated that, $P$. pelagicus reaches sexual maturity within one year at $9.6 \mathrm{~cm}$ carapace width. According to Sal-Moyano et al. (2014), the size at first sexual maturity differs with locations. In Lasongko Bay (Indonesia), Hamid et al. (2016) founded the $\mathrm{CW}_{50 \%}$ of male and female crab was 109.83 and $115.71 \mathrm{~mm}$ respectively.

The total instantaneous mortality $(\mathrm{Z})$ equaled 4.25 (Fig. 6). The instantaneous mortalities; natural (M) and fishing (F) equaled 1.6 and 2.65, respectively. Mortalities are an important factor in constructor of stocks. The absence of predators may be reflecting the lower of natural mortality of crab, that resulting abundance this species. Development of Sea bass stock in the lagoon is one of the important measures to control crab stocks. Invasive species are frequently associated with the decline of predator populations (Gurevitch and Padilla, 2004).

The size at first capture $\left(\mathrm{CWc}_{50}\right)$ of crab in this study equal $8.6 \mathrm{~cm}$ (Fig. 7). Dineshbabu $\boldsymbol{e t}$ al. (2008) estimated the carapace width at first capture in south Karnataka coast, India at $8.77 \mathrm{~cm}$.

The study concluded that, the stock of blue crab was characterized by lower of growth parameters, domination of small sizes and earlier 
Zagazig J. Agric. Res., Vol. 46 No. (3) 2019

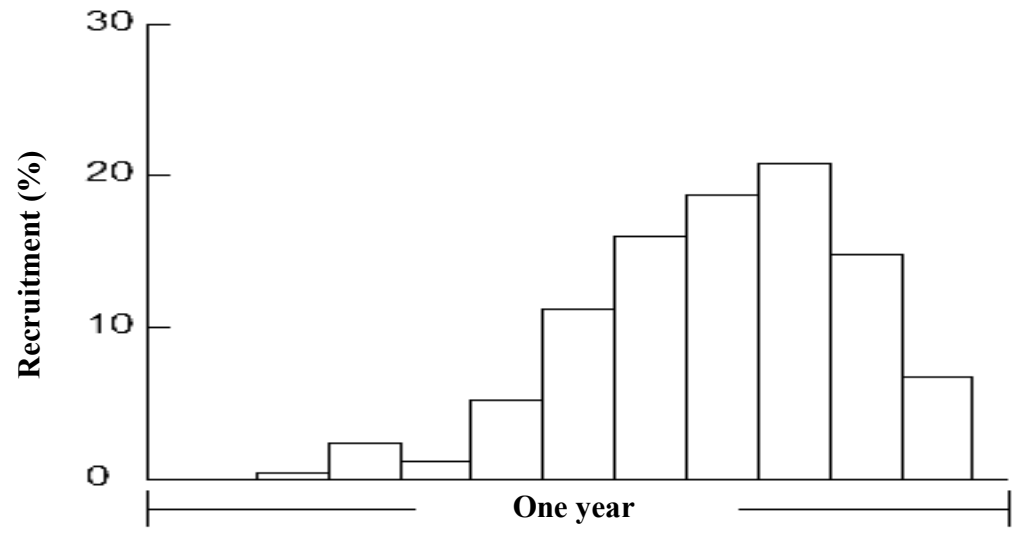

Fig. 5. Recruitment pattern of Blue crab

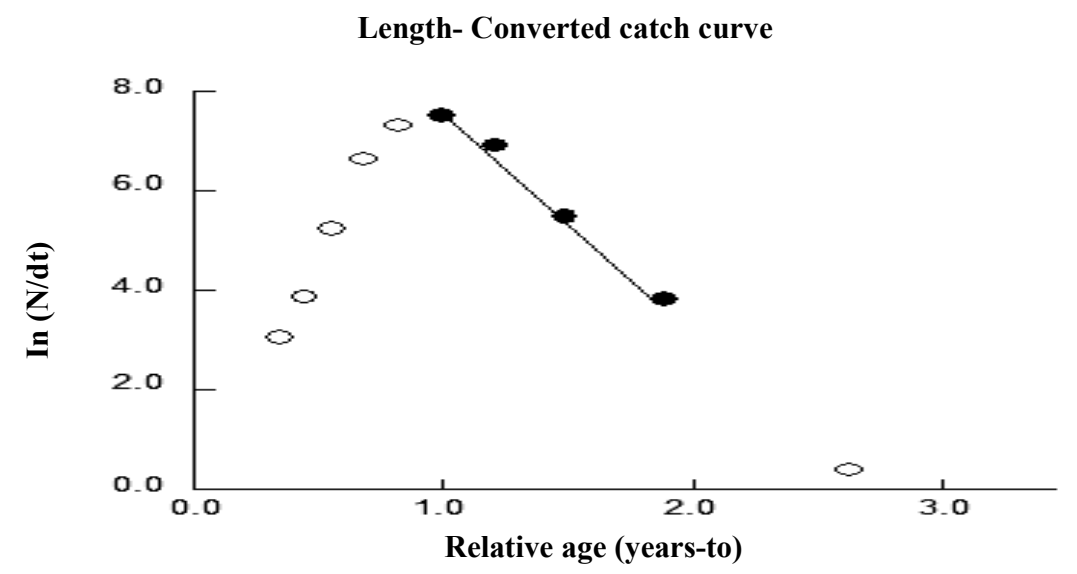

Fig. 6. Total mortality coefficient $(\mathrm{Z})$ of Blue crab

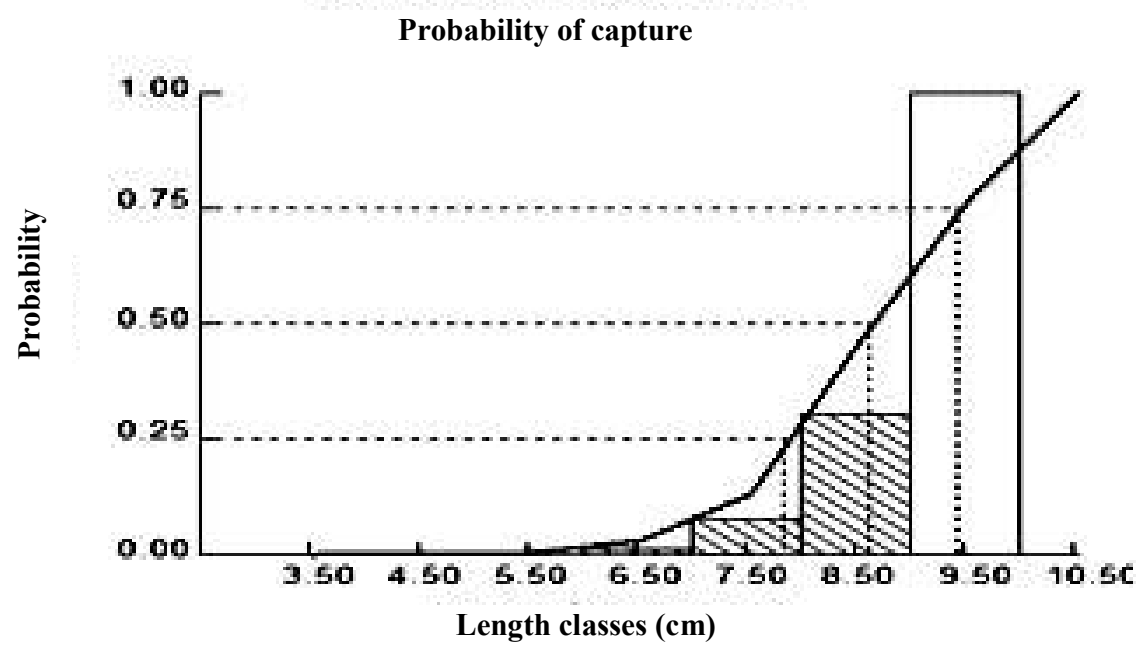

Fig. 7. Size at first capture $\left(\mathrm{CWc}_{50}\right)$ of Blue crab 
sexual maturity. These are indicators of the low economic importance of the species. Therefore, lower quality and price was observed compared with other species in the study area. The study recommended that, Blue crab in Bardawill lagoon may be become dangerous on native species; therefore, stock of this species in region should be controlled by: Increase the current fishing effort. Adding unconventional fishing methods such as traps with traditional fishing such as trammel trawlers and gillnetters. Development of predator stocks such as bass fish.

\section{Acknowledgement}

Author would like to thank the General Authority for Fisheries Development with special thanks to the management of Bardawill lagoon for technical support and facilitation of work.

\section{REFERENCES}

Abdel-Razek, F.A., M. Ismaiel, M.A.A. Ameran (2016). Occurrence of the blue crab Callinectes sapidus, Rathbun, 1896, and its fisheries biology in Bardawil Lagoon, Sinai Peninsula, Egypt. Egypt. J. Aquatic Res., 42 : 223-229.

Abdel-Razek, F.A., S.M. Taha and A.A. Ameran (2006). Population biology of the blue crab from lagoon Northern Sina, Egypt. National Institute of Oceanography and Fisheries Egypt, 1(32): 401-418.

Afzaal, Z., M.A. Kalhoro, M.A. Buzdar, A. Nadeem, F. Saeed, A. Haroon and I. Ahmed (2016). Stock assessment of blue swimming crab Portunus pelagicus (Linnaeus, 1758) from Pakistani Waters (Northern, Arabian Sea). Pak. J. Zool., 48 (5): 1531-1541.

Baylon, J. and H. Suzuki (2007). Effects of changes in salinity and temperature on survival and development of larvae and juveniles of the crucifix crab Charybdis feriatus (Crustacea: Decapoda: Portunidae). Aquac., $269:$ 390-401.

Dineshbabu, A.B., B. Shridhara and Y. Muniyappa (2008). Biology and exploitation of the blue swimmer crab, Portunus pelagicus (Linnaeus, 1758), from south Karnataka coast, India. Indian J. Fish., 55 (3): 215-220.
Ehsan, K., S. Abdul Nabi and Y. Maziar (2010). Stock Assessment and Reproductive Biology of the Blue Swimming Crab, Portunus pelagicus in Bandar Abbas Coastal Waters, Northern Persian Gulf. J. Persian Gulf, 1 (2): 11-22.

Emam, W. (2010). Ecological and population dynamics studies on some crab species in Bardawil Lagoon, Egypt. M.Sc. Thesis, Ain Shams Univ., Cairo.

Fisher, M.R. (1999). Effect of temperature and salinity on size at maturity of female blue crabs. Transactions of the Ame. Fisheries Soc., 128 (3): 499-506.

Foka, M.C., G. Kondylatos and P.S. Economidis (2004). Occurrence of the lessepsian species Portunus pelagicus (Crustacea) and Apogon pharaonis (Pisces) in the marine area of Rhodes Island. Mediterranean Marine Sci., 5: 83-89.

Froese, R. and C. Binohlan (2000). Empirical relationships to estimate asymptotic length, length at first maturity and length at maximum yield per recruit in fishes, with a simple method to evaluate length frequency data. J. Fish Biol., 56: 758-773.

GAFRD (2017). Annual reports of Bardawil lagoon. The General Authority for the Develop. Fish Res.

Gayanilo, F.C., P. Sparre and D. Pauly (2003). FAO-ICLARM stock assessment tool (FiSAT II) User's Guide, FAO Computerized Information Series (Fisheries). No. 8, Rome, FAO, 266.

Green, B.S., C. Gardner, J.D. Hochmuth and A. Linnane (2014). Environmental effects on fished lobsters and crabs. Rev. Fish Biol. and Fisheries 24:613-638.

Gurevitch, J. and D.K. Padilla (2004). Are invasive species a major cause of extinctions? Trends Ecol. Evol., 19: 470-474.

Hamid, A., T.F. Djamar, E. Riani, Y. Wardiatno (2016). Reproductive biology of blue swimming crab (Portunus pelagicus Linnaeus, 1758) in Lasongko Bay, Southeast Sulawesi-Indonesia. AACL Bioflux, 9: 5.

Hewitt, D.A. and J.M. Hoenig (2005). Comparison of two approaches for estimating natural 
mortality based on longevity. Fishery Bulletin., 103: 433-437.

Hosseini, M.A., V.Y. Parsa and A. Mansori (2012). Sex Ratio, Size Distribution and Seasonal Abundance of Blue Swimming Crab, Portunus pelagicus (Linnaeus, 1758) in Persian Gulf Coasts, Iran. World Appl. Sci. J., 17 (7): 919-925.

Ikhwanuddin, M., M.N. Azra, M.A.D. Talpur, A.B. AbolMunafi and M.L. Shabdin (2012). Optimal water temperature and salinity for production of blue swimming crab, Portunus pelagicus $1^{\text {st }}$ Day Juvenile Crab. Int. J. Bioflux Soc., 5 (1): 4-8.

Jayawiguna, M.H., M. Mulyono, E. Nugraha, H. Prayitno and A. Basith (2017). Biology aspect of blue swimming crabs (Portunus pelagicus) In Jakarta Bay waters, Indonesia. Aust. J. Basic and Appl. Sci., 11(13): 63-67.

Jensen, A.L. (1996). Beverton and Holt life history invariants result from optimal tradeoff of reproduction and survival. Can. J. Fish. Aquat. Sci., 53:820-822.

Josileen, J. and N.G. Menon (2004). Larval stages of blue swimmer crab, Роrtunus pelagicus (Linnaeus, 1758) (Decapoda, Brachyura). Crustaceana, 77 (7): 785-803.

Kilada, R. and N.K. Ibrahim (2016). Preliminary investigation of direct age determination using band counts in the gastric mill of the blue swimmer crab (Portunus pelagicus Linnaeus, 1758) In Two Salt-Water Lakes In The Eastern Mediterranean. J. Crustacean Biol., 36(2): 119-128.

Kunsook, C., N. Gajaseni and N. Paphavasit (2014). A stock assessment of the blue swimming crab Portunus pelagicus (Linnaeus, 1758) for Sustainable Management in Kung Krabaen Bay, Gulf of Thailand. Tropical Life Sci. Res., 25(1): 41-59.

Mehanna, S.F. and H.M. Haggag (2007). Fisheries management of the blue swimmer crab Portunus pelagicus (Linnaeus, 1766) from Port Said at the Mediterranean coast of Egypt. Proc. Int. Arab Afr. Fish Res. Conf., Sustainable use and Manag. Aquatic Res., 28-30.

Pauly, D. (1983). Length-converted catch curves: a powerful tool for fisheries research in the
Tropics (part 2). ICLARM, Fishbyte, 2 (1): 17-19.

Pauly, D. (1984). Fish population dynamics in tropical waters: a manual for use with programmable calculators. ICLARM Studies and Rev., $8: 325$.

Pauly, D. and J.I. Munro (1984). Once more on the comparison of growth in fish and invertebrates. Fish Byte, 2: 21-23.

Potter, I.C., S.D. Lestang and G.C. Young (1998). Influence of the Dawesville Channel on the recruitment, distribution and emigration of crustaceans and fish in the Peel-Harvey Estuary. FRDC Final Report, Project, 95/042, 61.

Romano, N. and C. Zeng (2006). The effects of salinity on the survival, growth and haemolymph osmolality of early juvenile blue swimmer crabs, Portunus pelagicus. Aquac., 26 (1): 151-162.

Rugolo, L., K. Knotts, A. Lange, V. Crecco, M. Terceiro, C. Bonzek, C. Stagg, R. O'Reilly, and D. Vaughn (1997). Stock assessment of Chesapeake Bay blue crab (Callinectes sapidus). National Marine Fisheries Service, NOAA Chesape ake Bay Stock Assess Ment Com Mittee, 267.

Sal-Moyano, M.P., A.M. Lagos-Tobias, D.L. Felder and F.L. Mantelatto (2014). Reproductive growth and reproductive parameters in a population of Microphrys bicornutus (Brachyura, Majoidea) from Bocas Del Toro, Caribbean Sea, Panama. Rev. Biol. Mar. Oceanogr, 49:81-90.

Smith, H. (1982). Blue crabs in South Australia - their status, potential and biology. SAFIC 6: 6-9.

Sugilar H., Y.C. Park, N.H. Lee, D.W. Han and K.N. Han (2012). Population dynamics of the swimming crab Portunus trituberculatus (Miers, 1876) (Brachyura, Portunidae) from the West Sea of Korea. Int. J. Oceanography and Marine Ecol. System, 1 (2): 36-49.

Walton, W.C., C. Mackinnon L.F. Rodriguez, C. Proctor and G.A. Ruiz (2002). Effect of an invasive crab upon a marine fishery: green crab, Carcinus maenas, predation upon a venerid clam, Katelysia scalarina, in Tasmania (Australia). J. Exp. Marine Biol. and Ecol., 272:171-189. 
بيولوجيا وديناميكية العشيرة للكابوريا الزرقاء السباحة Portunus pelagicus فى منخفض البردويل

$$
\begin{aligned}
& \text { محمد سالم أحمد } \\
& \text { كلية الاستزر اع المائى و المصايد البحرية - جامعة العريش - مصر }
\end{aligned}
$$

تُعتبر الكابوريا من القشريات البحريه الغريبه بمنخفض البردويل التى تحتاج الى الكثير من الدراسات، أستخدم التردد

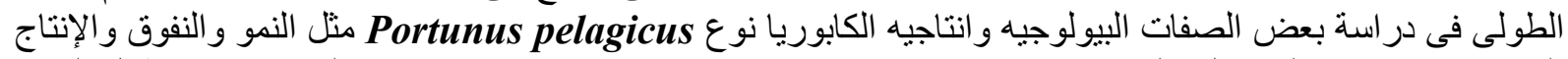

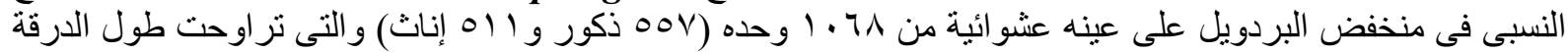

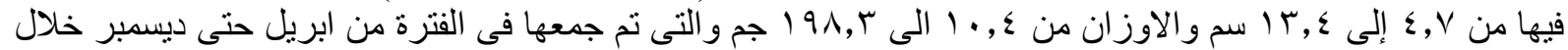

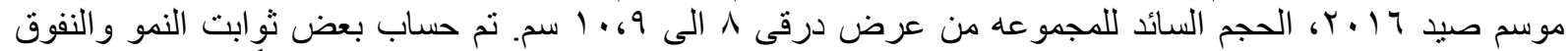

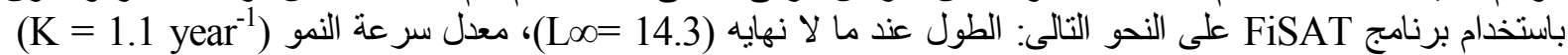

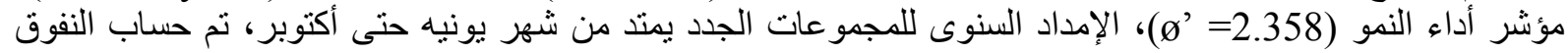

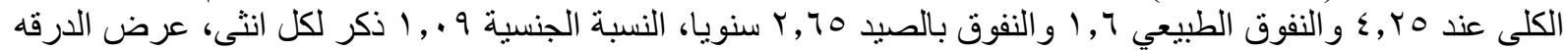

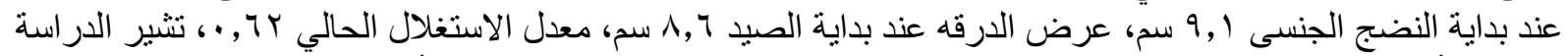

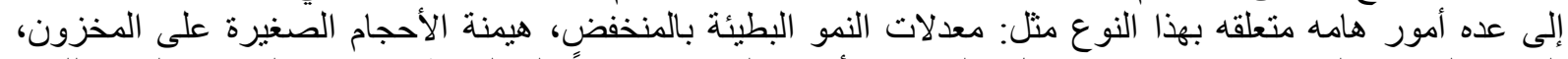

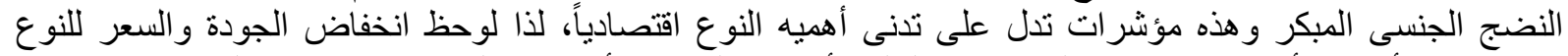

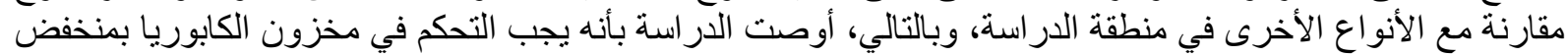

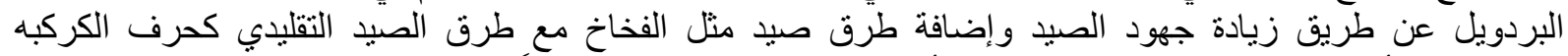

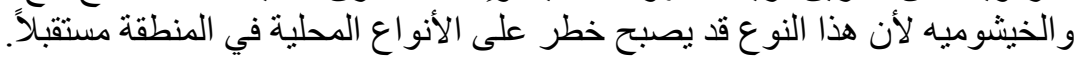

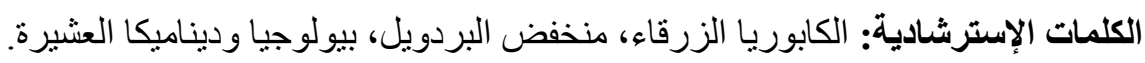

أستاذ ديناميكا العشائر ، المعهد القومي لعلوم البحار و المصايد.

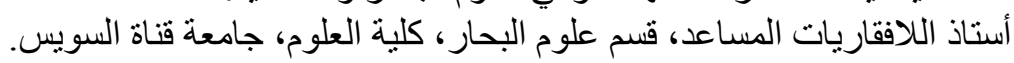

